\title{
TÖRETFELÜLETEK KVANTITATÍV JELLEMZÉSE
}

\author{
Sárközi Gábor, Kovács Jenő, Gácsi Zoltán
}

The stereological parameters of fractures are functions of the applied stresses and the mechanical and structural properties of the material. The characterisation of $3 D$ surfaces by means of consistent mathematical methods and the possibilities of the well-known microscopic techniques give new ways of scientific cognition of fracture processes. Our purpose is to develop relations between the parameters of fracture mechanics and the stereological character of the fracture surfaces. Recently we dealt with the profilometric characterisation of fracture surfaces of unalloyed steel probes. The probes had been broken with standard Charpy examination. The probes must be mounted to protect the profiles while polishing. Next we sectioned the surfaces. This paper deals with modes of polishing and mounting the probes in order to prepare them for evaluation by image analyser. Morphological transformations of the binary pictures are necessary to obtain the matrix of pixels appropriate for further investigations.

\section{Töretfelületek profilometriás jellemzése}

A töretfelületet a deformáció és a törési folyamatok eredményezik. A töret geometriai és az ezzel szorosan összefüggő mikroszerkezetbeli tulajdonságai kvantitatív információt hordozhatnak a törési folyamat végbemeneteléről. Az ezeket leíró matematikai összefüggéseknek és a vizsgálati technikáknak feltételezésektöl és viszonyítási alapoktól menteseknek kell lenniük.

A töretfelület egy fontos geometriai jellemzője lehet érdességének kvantitatív mérőszáma, a töretfelületi érdesség. Ennek mérése technikailag többféleképpen valósítható meg, például a felület vertikális metszeteiből a metszősíkon adódó, szabálytalan alakú görbék, a töretprofilok vizsgálata alapján.

A töretfelületi érdesség: $R_{S}=S / A$, ahol $S$ a töret valódi területe, $A$ pedig a topográfiai átlagsíkon képzett vetülete. A töretfelületi érdesség értéke teljesen sík felület esetén egy, általános esetben egytől a végtelenig változhat. A fent említett töretprofilok érdességét analóg módon értelmezhetjük: $R_{L}=\lambda / L$, ahol $\lambda$ a profil valódi hossza, $L$ a topográfiai átlagsíkon képzett vetületének hossza

Habár a profilérdesség és a töretfelületi érdesség jól meghatározott fizikai jelentéssel bírnak, valamint szükségszerü paraméterek a töret jellemzéséhez, önállóan nem definiálják a szabálytalan görbét vagy felületet. Felvehetők például olyan jellegzetesen különböző profilok, amelyek érdessége megegyezik. A különbség a profil- illetve a felületelemek szög szerinti eloszlásában rejlik, amennyiben a hosszuk 
összegének és a vetített hosszuknak aránya azonos. A szegmensek eloszlása egy választott iránnyal bezárt szögük alapján további információt hordozhat a törési folyamatokról, mivel ezt elsősorban a mikroszerkezet változásai és az ébredő feszültségeloszlás befolyásolhatják.

Egy közelítőleg sík lapokból álló, rideg, interkrisztallin töret felületelemeinek szög szerinti eloszlása a középérték körül kisebb ingadozással jelentkezik, míg egy gödröcskés, szívós töreten minden lehetséges irányban lesznek felületelemek, annak jellegéből fakadóan.

A Gokhale és Drury által 1992-ben kidolgozott módszer alapján kimutatható, hogy a töretfelület és a töretprofilok érdessége egymástól nem független. Amennyiben $\Psi$ jelöli a profil úgynevezett szerkezeti faktorát, amely a szükséges numerikus súlyozást és a profilelemek függőleges tengellyel bezárt szöge szerinti gyakoriságát tartalmazza [1,2], akkor a töretfelületi és a profilérdesség kapcsolata:

$$
R_{S}=\overline{R_{L} \Psi}
$$

A töretfelületi érdesség meghatározása ezek alapján az alábbi lépésekben hajtható végre:

- A síkmetszetek előállítása és a profilok szegmentálása.

- A profilérdesség meghatározása a szegmenshosszak és a vetületi hosszak hányadosaként.

- A szegmensek szög szerinti eloszlását jellemző hisztogram felvétele.

- A profilok szerkezeti faktorának számítása.

- A felületi érdesség számítása a profilérdességek és szerkezeti faktorok szorzatának a vizsgált síkmetszeteken vett átlagaként.

\section{A töretprofilok kiértékelésének módszere}

Szabványos hajlító-ütő vizsgálat során 0,$13 ; 0,37 ; 0,45 ; 0,60$ karbontartalmú ötvözetlen acél próbadarabokat vizsgáltunk. A próbatestek kimunkálása a rúdanyagok $950^{\circ} \mathrm{C}$-os normalizálását követően történt, így a darabok felületén nem maradt reve. A töretet a csiszolás és polírozás során történő károsodását elkerülendő különböző anyagokba ágyaztuk be. A beágyazóanyagokkal szemben támasztott követelmények:

- megfelelően nedvesítse a mintát, hogy behatoljon az üregekbe és polírozáskor ne váljon el a mintától,

- a darabbal közelítőleg azonos keménység, hogy polírozáskor se a beágyazó se a minta anyaga ne "kenődjön rá" a másikra, átlapolódások ne keletkezzenek,

- a próba átalakulási hőmérsékletétől alacsonyabb dermedési hőmérséklet,

- a mintadarabétól eltérő szín a fénymikroszkópos, vezetés és vákuumállóság a SEM vizsgálathoz.

\begin{tabular}{|l|l|l|}
\hline \multicolumn{1}{|c|}{ Beágyazóanyag } & \multicolumn{1}{c|}{ Tapasztalatok, problémák } & \multicolumn{1}{c|}{ Értéke lés, magyarázat } \\
\hline $\begin{array}{l}\text { Vezetö fenolgyanta } \\
\text { (sajtolás: } 12000 \text { psi) }\end{array}$ & $\begin{array}{l}\text { az üregeket a nagy sajtolóerö miatt jól } \\
\text { kitölti, legömbölyödés }\end{array}$ & $\begin{array}{l}\text { elporlik a polírozás során, így } \\
\text { mindig kissé jobban kopik }\end{array}$ \\
\hline STRUERS mügyanta & $\begin{array}{l}\text { a profil “legömbölyödik", részben } \\
\text { elválik a felülettőll }\end{array}$ & eltérö keménység, rossz nedvesítés \\
\hline Alumínium & $\begin{array}{l}\text { elválik a felülettöl, lyukak a profil } \\
\text { mentén }\end{array}$ & rossz nedvesítés \\
\hline $\mathrm{Al}-\mathrm{Al}_{2} \mathrm{Cu}$ eutektikum & elválik a felülettöl, lyukak a profil & rossz nedvesítés még fémtiszta (12\% \\
\hline
\end{tabular}




\begin{tabular}{|l|l|l|}
\hline$(33,5 \%)$ & mentén & HCl) felületen is \\
\hline $\begin{array}{l}\text { Réz, valamint } \\
\mathrm{Cu}-\mathrm{kb} .6 \% \mathrm{Sn} \text { ónbronz }\end{array}$ & $\begin{array}{l}\text { rákenödik a felületre, viszont jól követi } \\
\text { a profilt }\end{array}$ & $\begin{array}{l}\text { eltérö keménység, jó nedvesítés; } \\
\text { szelektív oldás szükséges }\end{array}$ \\
\hline $\mathrm{Cu}-37 \% \mathrm{Zn}$ sárgaréz & $\begin{array}{l}\text { jól követi a profilt, csekély mértékben } \\
\text { töredezik }\end{array}$ & $\begin{array}{l}\text { jó nedvesítés, eltérő hőtágulás, } \\
\text { megmunkálásra érzékeny }\end{array}$ \\
\hline $\begin{array}{l}\text { Durakryl mügyanta }+ \\
\text { saját anyag reszeléke }\end{array}$ & & $\begin{array}{l}\text { nem különböztethető meg a minta a } \\
\text { beágyazóanyagtól }\end{array}$ \\
\hline $\begin{array}{l}\text { Vezető mügyanta }+\mathrm{SiC} \\
\text { por }(30 . .70 \mu \mathrm{m})\end{array}$ & nem tölti ki az üregeket & $\begin{array}{l}\text { a SiC elfedi az üregeket, így a } \\
\text { gyanta nem sajtolódik bele }\end{array}$ \\
\hline
\end{tabular}

\section{A profilok kiértékelése}

A profilok Quantimet 570C képelemzővel történő vizsgálata során az alábbi megállapítható, hogy a beágyazóanyag helyes megválasztása - és gondos polírozás - esetén a próbadarab anyaga a beágyazó anyagtól jól elkülöníthetö. Az ehhez rendelhető szürkeségi szint kiválasztásával kapott bináris képből az annak eróziójával keletkezettet kivonva egyetlen pixel szélességü vonalat kapunk, amely pontosan az általunk kiértékelni kívánt profil.

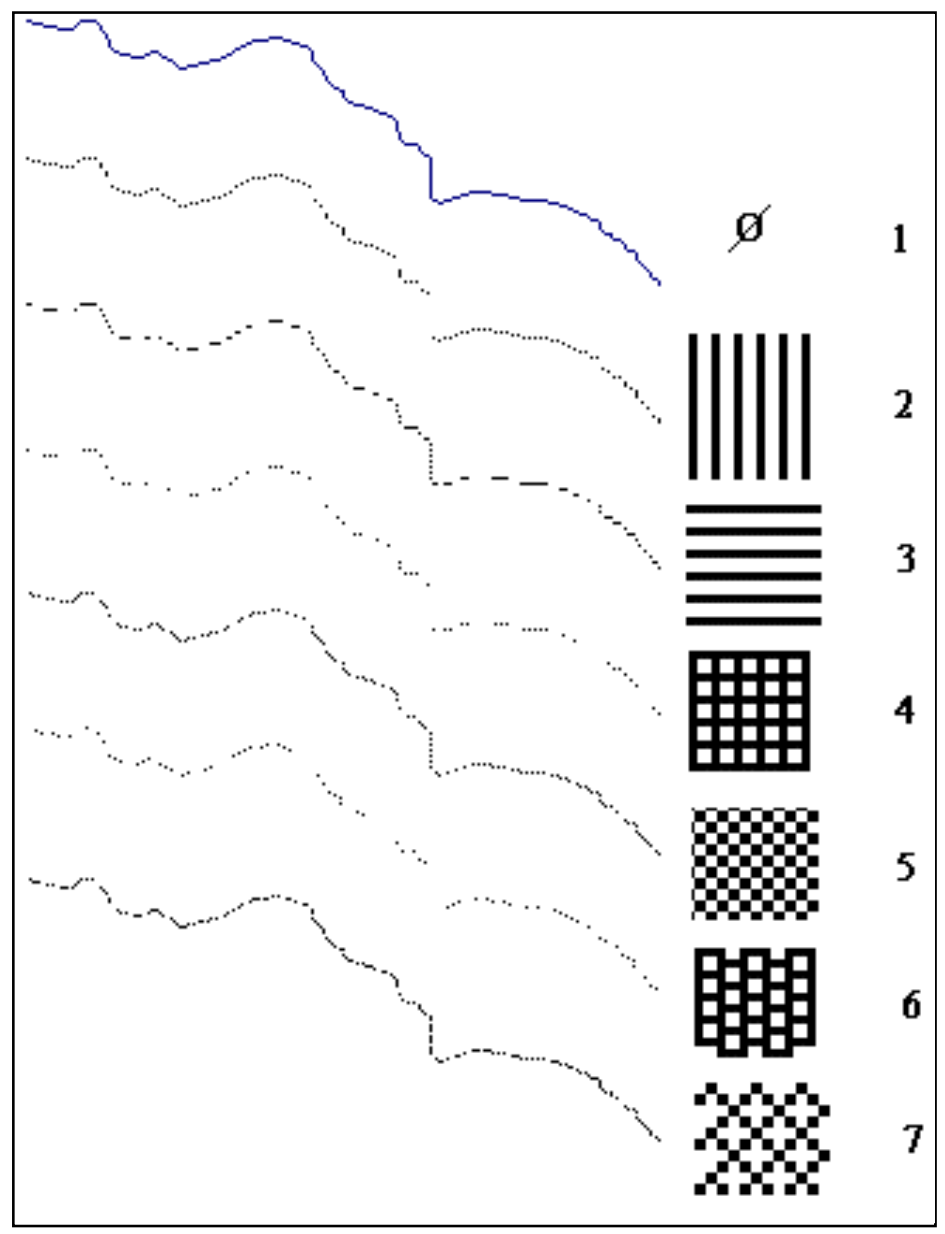

1. ábra - A "kivont" rácsok és az eredmény

A következő lépésben határozzuk meg a felvett 512x512 képpontos mátrixban a vonal pontjainak 
koordinátáit! A képelemző szoftverével ez egyetlen lépésben elvégezhető, azonban a program objektumonként csak egy pontot vesz figyelembe. Egy objektumhoz tartoznak a lapjukon érintkező pontok, így az ugyancsak mért objektumterületekből meghatározható az adott objektumot alkotó pixelek száma.

Az objektumonként figyelembe vett (és a képelemző által elmentett) koordináta-pár lehet az objektum "középső" pontja (centruma), valamint lehet annak "első" pontja, amennyiben a detektálás valamely koordináta szerint történik. Így gyakorlatilag jelentős számú pont tűnik el a kiértékelő számára. A hiányzó pontok azonban $\mathrm{x}$ vagy $\mathrm{y}$ irányú lineáris változást takarnak, így próbálkozhatunk ezek utólagos pótlásával. Ekkor a nehézséget azon algoritmus megtalálása jelenti, amelynek alapján sorba rendezhetnénk a valóságban szabálytalan görbén fekvö, egymástól szabálytalan távolságban felvett pontokat. Tudniillik egy esetleges átlapolódás meghiúsítja a legígéretesebbnek tünő rendezési elvet is.

A megoldást a bináris kép megfelelő átalakítása jelentheti. Amennyiben az objektumok méretét egyetlen pixelnyire tudjuk csökkenteni (csak csúcsokon érintkezzenek), akkor - mivel objektumonkét egy pontot detektálunk - az összeset figyelembe vesszük. Némi áldozat árán ezt is elérhetjük: vonjunk ki a bináris képből (vonal) egy megfelelően konstruált rácsot, azaz daraboljuk fel az objektumokat! Ekkor néhány pont ugyan eltünik, ám ezek száma jóval alatta marad azokénak, amelyeket az eredetileg több pontnyi objektumokból pótlólagosan figyelembe veszünk. Kérdezhetjük:

- Mely rács esetén egyetlen pixel méretü az összes objektum?

- Mely rács esetén veszítjük el a lehetö legkevesebb pontot?

\section{A kivont rácsok típusa és az így nyert eredmény}

Az 1. ábra az alkalmazott rácsokat és az ezzel nyert eredményt mutatja. Az 1 számú profil a kiindulási állapotot mutatja $\left(C 60 \mathrm{~T}_{\mathrm{R}}\right.$ 1000x). A 2, 3, 7 jelzésü rácsok esetén az objektumok továbbra is több négyzetpixel területüek. A 4, 5, 6 ábrák ígéretesebbek: profiltól függően alkalmazandók, annak átlapolódásaitól függően. Jelen esetben a legjobb eredményt az 5 számú rács biztosítja.

Mindezek után első közelítésben rendezési elvként szolgálhat a legközelebbi pontok összekötése, amivel a profilok kiértékelése elvégezhető.

\section{Felhasznált irodalom}

1. Gokhale, A. M. and Underwood, E. E.: "A General Method for Estimation of Fracture Surface Roughness: Part I. Theoretical Aspects", Met. Trans. A, Vol. 21A, 1990, p. 1193-1199.

2. Gokhale, A. M. and Drury, W. J.: "A General Method for Estimation of Fracture Surface Roughness: Part II. Practical Considerations”, Met. Trans. A, Vol. 21 A, 1990, p. 1201-1207.

Dr. Gácsi Zoltán, egyetemi docens; Kovács Jenő, doktorandusz;

Sárközi Gábor, egyetemi hallgató; Miskolci Egyetem, Fémtani Tanszék, H-3515 Miskolc-Egyetemváros, Hungary

Tel.: 46/366-111, E-mail: qkosgabi@gold.uni-miskolc.hu 